\title{
Customs Duty Evasion Issues in Nepal
}

\author{
Gautam Maharjan, PhD * \\ maharjangautam@gmail.com
}

\begin{abstract}
The main objective of this study is to identify the magnitude of issues relating to customs duty evasion in Nepal. Judgmental sampling technique has been applied with the total of 819 respondents: 421 from business communities and 398 from government officials. Descriptive statistics and compare mean test has been used for the data analysis. From the ranking analysis, it is concluded that respondents are more serious on the issue of 'difficulties in managing open border', 'ambiguous customs policy' and 'poor infrastructure and inconvenient location' which were ranked first, second and third respectively. However, the respondents become less serious in the issue of 'poor technology adoption' which is ranked last (seventh). The mean scores on each issue were above three and it indicates that the respondents agree on seriousness of the customs duty evasion. However, the mean difference test across business communities and government officials on each issue were found to be significantly different as the mean scores for business communities were higher. Identification of the seriousness on the issues of customs duty evasion in this study could be advantageous for the revenue planner to make newer customs policy.
\end{abstract}

Keywords: Customs duty evasion, Open border, Customs policy, Infrastructure and location, Technology

\section{Introduction}

Customs duty is defined as duty chargeable on goods to be exported or imported in accordance with laws (DoC, 2007). In other words customs revenue is a tax imposed on imports and exports of commodities through country boundaries (Singh, 2010). Tax evasion in customs occurs mainly through misclassification and undervaluation of imports in developing countries. This in fact also occurs due to threat of higher valuation and lengthy time for customs clearance, thus encouraging importers to engage in illegal settlement. King (2003) indicated a practice of under-invoicing and lack of effective valuation process in developing countries. The study highlighted the necessity of capacity development for implementation of customs valuation system. In the same fashion, Ghimire (2005) identified the discretionary power of customs authorities in Nepal as a major issue with customs valuation process.

Finger and Schuler (2000) also observed that the customs valuation agreement provides neither appropriate diagnosis nor appropriate remedy for least developed countries problems

* Faculty at Public Youth Campus, Tribhuvan University. This paper was presented in the 1st Global International Conference dated 13-14 December 2019.

NJMSR V. 3 Issue 2 (2019) 
with customs administration. They suggested capacity building in the form of introduction of IT systems and database to customs for sound implementation of agreement as proper administrative environment does not exist in many developing countries. Trade liberalization shows a negative association with total tax revenue and international trade tax revenues (Khattry \& Rao, 2002). Bhagwati (1964) argued that the discrepancies between reported imports and corresponding exports by trading partners could be explained by undervaluation and misclassification of imports to reduce the burden of tariff.

Rege (2002) accounted the resentment of developing countries for the application of transaction values as it would supposedly decrease the customs revenue due to undervaluation. The study on effect of technology on revenue collection by Embu County Government, Kenya, concluded that the technological advancements positively affect revenue collection (Karimi, Kimani, \& Kinyua, 2017).

Amin, Nadeem, Parveen, Kamran and Anwar (2014), in their empirical investigation on factors affecting tax collection in Pakistan, concluded that the tax collection reduced due to corruption, inflation and political instability; whereas, trade openness and real per capita income increase the revenue.

Awan (2014) highlighted six main causes of tax evasion: unproductive expenditures / misuse of funds, anti-tax culture, corrupt tax administration, multiple \& higher tax rates, complex tax system and amnesties and incentives for tax evaders.

Wei (2013) found that inefficient knowledge management, misuse of trade facilitation standards or misunderstanding of multilaterally acknowledged trade rules on the part of both policymakers and administrators might create distortions to Customs' mandate. The traders in Bangladesh faced delays due to excessive official formalities, inefficiencies and arbitrary discretion in conducting their trade, especially in Customs and the Port Authority (Uzzaman \& Yusuf, 2011).

The average size of informal economy in Nepal was found to be about 40 percent of official economy during the period of 2001/02-2009/10. Further, it also showed a significant impact on total revenue loss for Nepalese customs (Paudel, 2010).

Taneja and Pohit (2004) reported that Raxaul, Naxalbari, Jogbani, Nautanwa Barhni in India emerged as the important centers of informal trade in India whereas Kankkadvita, Biratnagar, Birgunj, Bhairahawa, and Nepalgunj are noted as the important informal trading centers in the Nepalese territory.

Ghimire (2006) estimated evasion was more than 40 percent of taxable capacity. The study found that the penalty provisions of the Customs Act 1962 could not be implemented perfectly. Informal and unauthorized part covered a large volume which was around 38.9 percent of the formal import from India to Nepal (MountDigit Technology, 2006). German Development Cooperation (2015) also found tax evasion is the function of high tax rate, low penalty rate, low possibility of detection of the fraud, weak administration and its behaviour towards taxpayers.

The major reasons as identified by the past studies are the presence of poor technology adoption, weak customs administration, poor human resource base, and the poor customs infrastructure. The past studies also do not provide the evidence on the aggregate responses 
Customs Duty Evasion Issues in Nepal

of business communities and government officials about importance of several factors associated with customs duty evasion. Similarly, none of the past studies have done cross sectional analysis and identified issues in the order of seriousness.

It has been well understood that customs duty evasion negatively affects the customs revenue. The most common problem in a developing country like Nepal is the difficulty in achieving the desired economic growth primarily due to the lack of adequate revenue generation.

\section{Literature Review}

Akindele (2011) has revealed that insufficient training, barriers in communication and bad management skills are the root cause of fraud in the organization. Abodher, Ariffin and Saad (2018) revealed that both political affiliation and political instability have a significant effect on tax non-compliance among self-employed Libyans. Tax-evasion goods and use of agents to import goods substantially affect small business performance in open border region (Paudel \& Devkota, 2018).

According to Bridi (2010), tax officials are those who are responsible for the administration of tax collection and enforcement, including the registration and removal of tax-payers from the national registry, the collection of tax dues (filling, payment and processing), the identification prosecution of alleged tax offences. Similarly OECD report (2014), said that tax officers also play an important role in combating corruption as in the course of their work they may uncover corruption and other wrongdoings.

Mishra, Subramanian and Topalova (2007) found a significant and robust impact of tariffs policy on evasion. It was found among others that Transit and Warehousing activities have a lot of rot being perpetuated independently and collectively by importers and tax officials (Adu1, Poku \& Anarfi, 2014).

Randrianarisoa, Bolduc, Choo, Oum and Yan (2015) revealed in their study that strong evidence of negative impacts of corruption on airport operating efficiency using panel data for selected European airports between 2003 and 2009.

Delays in clearance of goods and evasion of duties will negatively impact the efficiency of customs services. Corruption negatively affects the absolute effectiveness of customs clearance process (Onogwu, 2018).

Edirisinghe (2013) has underlined one of the key components is infrastructure in international logistic performance. Infrastructure comprises ports, railroads, roads, information technology assessing the quality of trade-and-transport. So, in order to control the customs evasion, infrastructure facilities should be provided adequately and effectively.

In this way, several research studies are available in the area of tax evasion in the countries around the globe and many of them provide conflicting views in the behaviour of customs duty evasion. In Nepal there is a dearth of such literature regarding the different issues related to customs duty evasion. Therefore, the present study attempts to address the magnitude of issues related customs duty evasion based on Nepalese experience in border tax management.

From the literature review, following research questions have been developed to study the magnitude of issues relating to customs duty evasion in Nepal.

NJMSR V. 3 Issue 2(2019) 33 
What is the magnitude of the issues like "poor technology adoption (PTA)"?

What is the magnitude of the issues like "political disturbance (PD)"?

What is the magnitude of issues on "difficulties in managing open border (OB)"?

What is magnitude of issue on "poor human resource base (PHR)"?

What is the magnitude of issue on "ambiguous customs policy (ACP)"?

What is the magnitude of issue on "poor infrastructure and inconvenient location (PIIL)"?

What is magnitude of issue on "Lengthy customs clearance procedure (LCCP)"?

In the light of the stated problems, the study has the objective of assesing the magnitude of issues relating to customs duty evasion in the business communities and government officials in Nepal. Further, the study also attempts to identify the degree of seriousness of the stakeholders on the issues. The issues associated with customs duty evasion system are- (1) Poor technology adoption (PTA), (2) Political disturbance (PD), (3) Difficulties in managing open border (OB), (4) Poor human resource base (PHR), (5) Ambiguous customs policy (ACP), (6) Poor infrastructure and inconvenient location (PIIL), and (7) Lengthy customs clearance procedure (LCCP).

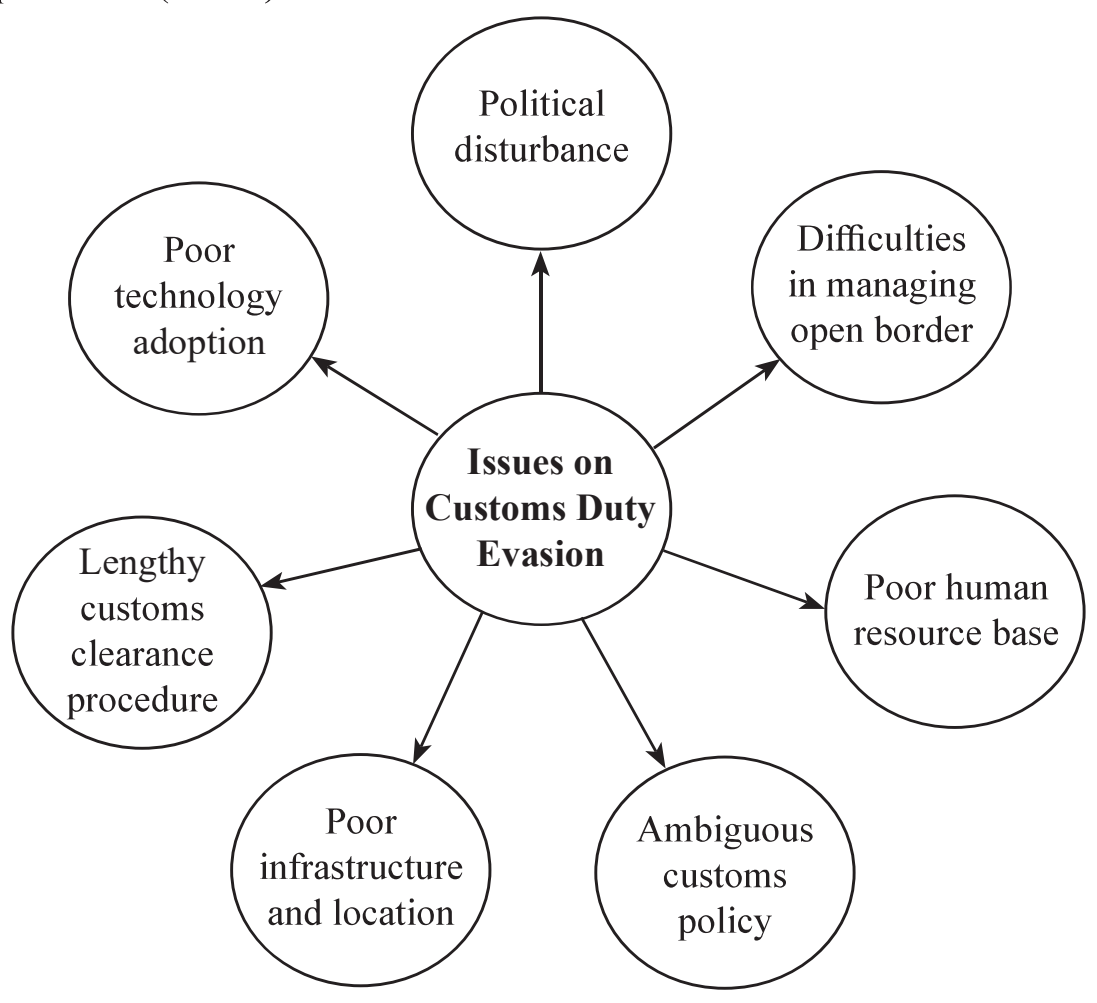

Figure 1. Research framework on issues on customs duty evasion.

\section{Data and Methodology}

Descriptive and analytical research design have been used in this study to identify the seriousness of stakeholders on the issues related to customs duty evasion in Nepal. Data was obtained from opinion survey. It was collected from major customs points and concerned stakeholders of different places of Nepal through questionnaires. The responses are measured in a Five point Likert scale for various sorts of problem statements. 
Customs Duty Evasion Issues in Nepal

The scale of responses are numbered as 1 for 'not agree', 2 for 'somehow agree', 3 for 'fairly agree', 4 for 'agree', and 5 for 'strongly agree'. The data focuses on seven different issues relating to customs duty evasion determines from past studies. The perceptions of stakeholders have been collected to determine the most serious and the least serious factors on customs duty evasion among the seven issues. The seven issues on customs duty evasion [ie, poor technology adoption (10), political disturbance (06), difficulties in managing open border (06), poor human resource base (10), ambiguous customs policy (10), poor infrastructure and inconvenient location (10), and lengthy customs clearance procedure (11)] were evaluated for the seriousness on the issues. The number of respondents were 819. Out of the total respondents, 421 were from business communities and 398 from government officials, were taken as a sample for this study. Independent sample mean test was employed to compare the perception of both groups- business communities and government officials on the issues of customs duty evasion. The percentages of total mean score were also distributed and ranked to identify the degree of seriousness on each issue related to customs duty evasion.

\section{Study Results and Discussion}

Responses were collected from the opinion survey. The opinion survey of various stakeholders (business communities and government officials related to customs revenue) shows the average scores on seven issues. Table 1 depicts that distribution of respondents on the basis of mean scores and standard deviation obtained in various categories of issues. Each of the issue categories contains six to eleven statements. The result reveals that the respondents are experiencing more problems on the seven different issues.

\subsection{Descriptive Statistics}

According to business communities' views, the highest mean score (3.876) lies in 'ambiguous customs policy' whereas the lowest mean score (3.609) lies in 'poor technology adoption'. But the lowest standard deviation (0.569) and the highest standard deviation (0.705) lie in 'ambiguous customs policy' and 'difficulties in managing open border' respectively. Similarly, from the point of view of government officials, the highest mean score of 3.642 lies in 'difficulties in managing open border' whereas the lowest mean score (2.925) lies in 'poor technology adoption'. But the highest standard deviation of scores $(0.881)$ lies in 'poor technology adoption' and the lowest (0.616) lies in 'ambiguous customs policy'. The structure of mean and standard deviation of both groups are also similar with total respondents.

From the analysis of business communities' perception on the basis of mean scores, the respondents are more serious on the issue of 'difficulties in managing open border' but the corresponding standard deviations reflects the views on the issue are seen as ups and downs. Similarly, the view of government officials as well as in total respondents are more serious in 'difficulties in managing open border' but less serious in 'poor technology adoption'. But the highest standard deviation of the scores in 'poor technology adoption' reveals the perceptions of the respondents on this issue are not consistent among the seven issues. However the standard deviations of scores of all groups are low in 'ambiguous customs policy'. This indicates that the respondents' views on the issue of 'ambiguous customs policy' have more consistency. Eventually, the average views of total respondents are similar with the views of government officials.

NJMSR V. 3 Issue 2(2019) 35 
Customs Duty Evasion Issues in Nepal

Table 1

Response of Stakeholders on the Issues of Customs Duty Evasion

\begin{tabular}{lccccccc}
\hline \multicolumn{1}{c}{ Issues of Customs Duty Evasion } & \multicolumn{2}{c}{$\begin{array}{c}\text { Business } \\
\text { Communities } \\
\text { (421) }\end{array}$} & $\begin{array}{c}\text { Government } \\
\text { Officials } \\
\mathbf{( 3 9 8 )}\end{array}$ & $\begin{array}{c}\text { Total } \\
\mathbf{( 8 1 9 )}\end{array}$ \\
\cline { 2 - 8 } & Mean & SD & Mean & SD & Mean & SD \\
\hline Poor technology adoption & 3.609 & 0.681 & 2.925 & 0.881 & 3.276 & 0.855 \\
Political disturbance & 3.733 & 0.670 & 3.334 & 0.811 & 3.539 & 0.768 \\
Difficulties in Managing open border & 3.776 & 0.705 & 3.642 & 0.698 & 3.711 & 0.704 \\
Poor human resource base & 3.782 & 0.662 & 3.366 & 0.787 & 3.579 & 0.754 \\
Ambiguous customs policy & 3.876 & 0.569 & 3.442 & 0.616 & 3.665 & 0.631 \\
Poor infrastructure and inconvenient location & 3.868 & 0.594 & 3.419 & 0.724 & 3.650 & 0.697 \\
Lengthy customs clearance procedure & 3.836 & 0.599 & 3.299 & 0.674 & 3.575 & 0.690 \\
\hline & \multicolumn{3}{c}{ Source: Author's calculation from Survey 2015}
\end{tabular}

\subsection{Levene's Test}

Table 2 reports Levene's test for equality of variances for both groups of business communities and government officials. Among seven different issues, Levene's F-Statistic shows that all the issues are significant at 1 percent and 5 percent level except two issues- (1) difficulties in managing open border and (2) ambiguous customs policy. So, equality of variances is not assumed for all issues except for 'difficulties in managing open border and ambiguous customs policy for independent samples test (t-Test for two sample mean). So, equality of variances is assumed for these two issues to test the compare means of both groups.

Table 2

Levene's Test for Equality of Variances

\begin{tabular}{lcccc}
\hline \multicolumn{1}{c}{ Issues of Customs Duty Evasion } & F-Statistic & p-value & $\begin{array}{c}\text { Sig. } \\
\text { Level }\end{array}$ & $\begin{array}{c}\text { Equality of } \\
\text { Variance }\end{array}$ \\
\hline Poor technology adoption & 43.030 & 0.000 & $<0.01$ & Not assumed \\
Political disturbance & 16.630 & 0.000 & $<0.01$ & Not assumed \\
Difficulties in managing open border & 0.010 & 0.920 & $>0.10$ & Assumed \\
Poor human resource base & 15.749 & 0.000 & $<0.01$ & Not assumed \\
Ambiguous customs policy & 1.926 & 0.166 & $>0.10$ & Assumed \\
Poor infrastructure and inconvenient location & 23.478 & 0.000 & $<0.01$ & Not assumed \\
Lengthy customs clearance procedure & 4.656 & 0.031 & $<0.05$ & Not assumed \\
\hline
\end{tabular}

Source: Author's calculation from Survey 2015

\subsection{Compare Mean Test}

Table 3 demonstrates the deference mean-scores and corresponding t-statistics of each issue of customs duty evasion between two groups of stakeholders (Business communities and Government officials). The result reported that all corresponding p-values of each issue are less than $0.01(1 \%)$. This indicates that the mean differences of both groups are significant at 1 percent level in all issues. This means that there is a significant difference of mean-scores between two groups. Therefore, it is clearly understood that the perception between business communities and government officials are different in each issue. 
Customs Duty Evasion Issues in Nepal

Table 3

t-Test for Equality of Means

\begin{tabular}{lccrcc}
\hline \multicolumn{1}{c}{ Issues of Customs Duty Evasion } & Df & $\begin{array}{c}\text { Mean } \\
\text { Difference }\end{array}$ & $\begin{array}{c}\text { t- } \\
\text { Statistic }\end{array}$ & $\begin{array}{c}\text { p- } \\
\text { value }\end{array}$ & $\begin{array}{c}\text { Sig. } \\
\text { Level }\end{array}$ \\
\hline Poor technology adoption & 746.748 & 0.684 & 12.377 & 0.000 & $<0.01$ \\
Political disturbance & 771.020 & 0.399 & 7.654 & 0.000 & $<0.01$ \\
Difficulties in Managing open border & 817.000 & 0.135 & 2.742 & 0.006 & $<0.01$ \\
Poor human resource base & 777.268 & 0.416 & 8.161 & 0.000 & $<0.01$ \\
Ambiguous customs policy & 817.000 & 0.434 & 10.470 & 0.000 & $<0.01$ \\
Poor infrastructure and inconvenient location & 768.584 & 0.448 & 9.655 & 0.000 & $<0.01$ \\
Lengthy customs clearance procedure & 793.310 & 0.537 & 12.025 & 0.000 & $<0.01$ \\
\hline & \multicolumn{5}{c}{ Source: Author's calculation from Survey 2015 }
\end{tabular}

\subsection{Seriousness of Business Communities on the Issues of Customs Duty Evasion}

Based on the response of the business communities for the issues on customs duty evasion, an attempt has been made to present the mean score of each issue. Rounding the mean scores, Table 4 depicts that the mean score of each issue of customs duty evasion is nearly 4 which lie in 'agree' scale of response.

Table 4

Perception of Business Communities on the Issues of Customs Duty Evasion with Scale of Responses

\begin{tabular}{|c|c|c|c|}
\hline Issues of Customs Duty Evasion & $\begin{array}{l}\text { Mean } \\
\text { Score }\end{array}$ & $\begin{array}{l}\text { Rounding } \\
\text { Scores }\end{array}$ & $\begin{array}{c}\text { Scale of } \\
\text { Response }\end{array}$ \\
\hline Poor technology adoption & 3.61 & 4 & agree \\
\hline Political disturbance & 3.73 & 4 & agree \\
\hline Difficulties in Managing open border & 3.78 & 4 & agree \\
\hline Poor human resource base & 3.78 & 4 & agree \\
\hline Ambiguous customs policy & 3.88 & 4 & agree \\
\hline Poor infrastructure and inconvenient location & 3.87 & 4 & agree \\
\hline Lengthy customs clearance procedure & 3.84 & 4 & agree \\
\hline Average & 3.78 & 4 & agree \\
\hline
\end{tabular}

Source: Author's calculation from Survey 2015

In this process, average scores of business communities are computed as percentage and ranked in order of seriousness. As presented in Table 5, the level of responses of the business communities shows that 'ambiguous customs policy' has captured 14.64 percent of total scores and ranked as the number one issue. Similarly, "poor infrastructure and inconvenient location' (14.61\%) and 'lengthy customs clearance procedure'(14.49\%) are ranked two and three respectively while poor technology adoption has captured only 13.67 percent and ranked as the least serious issue among the seven related issues of the customs duty evasion. Therefore, from the view point of business communities, 'ambiguous customs policy', 'poor infrastructure and inconvenient location' and 'lengthy customs clearance procedure' are the more serious issues of customs duty evasion. 
Customs Duty Evasion Issues in Nepal

Table 5

Rank of Various Issues Related to Customs Duty Evasion in the View of Business Communities

\begin{tabular}{lccc}
\hline \multicolumn{1}{c}{ Issues of Customs Duty Evasion } & Mean Score & $\mathbf{\%}$ & Rank \\
\hline Poor technology adoption & 3.61 & 13.63 & 7 \\
Political disturbance & 3.73 & 14.10 & 6 \\
Difficulties in Managing open border & 3.78 & 14.26 & 5 \\
Poor human resource base & 3.78 & 14.28 & 4 \\
Ambiguous customs policy & 3.88 & 14.64 & 1 \\
Poor infrastructure and inconvenient location & 3.87 & 14.61 & 2 \\
Lengthy customs clearance procedure & 3.84 & 14.49 & 3 \\
& Total & 26.48 & 100 \\
\hline
\end{tabular}

\subsection{Seriousness of Government Officials on the Issues of Customs Duty Evasion}

According to perception of government officials, mean scores of each issue related to customs duty evasion have been also presented. Table 6 shows that the mean score of the issue of 'difficulties in managing open border' is nearly 4.

According to distribution of scale, response at 4 lies in 'agree' scale of response. However, all other scores related to customs duty evasion are nearly 3 which indicate 'fairly agree' scale of response. However, on an average mean score of the total issues reaches at 3.35 that is nearly 3. This result also indicates that the average perception of government officials is observed as 'fairly agree' on the issues of customs duty evasion.

Table 6

Perception of Government Officials on the Issues of Customs Duty Evasion with Scale of Responses

\begin{tabular}{|c|c|c|c|c|}
\hline Issues of Customs Duty Evasion & & $\begin{array}{l}\text { Mean } \\
\text { Score }\end{array}$ & $\begin{array}{c}\text { Rounding } \\
\text { Score }\end{array}$ & $\begin{array}{c}\text { Scale of } \\
\text { Response }\end{array}$ \\
\hline Poor technology adoption & & 2.92 & 3 & fairly agree \\
\hline Political disturbance & & 3.33 & 3 & fairly agree \\
\hline Difficulties in Managing open border & & 3.64 & 4 & Agree \\
\hline Poor human resource base & & 3.37 & 3 & fairly agree \\
\hline Ambiguous customs policy & & 3.44 & 3 & fairly agree \\
\hline Poor infrastructure and inconvenient location & & 3.42 & 3 & fairly agree \\
\hline Lengthy customs clearance procedure & & 3.30 & 3 & fairly agree \\
\hline & Average & 3.35 & 3 & fairly agree \\
\hline
\end{tabular}

As presented in Table 7, mean scores of government officials are computed and ranked in order of seriousness. The responses of the government officials shows that issues on 'difficulties in managing open border' covers 15.45 percent of total mean scores and has been ranked first, then, 'ambiguous customs policy' (14.69\%) and 'poor infrastructure and 
inconvenient location' (14.60\%) ranked second and third respectively while 'poor technology adoption' which covered only 12.49 percent which has been ranked as the least serious issue of the customs duty evasion among the seven issues. As government officials' point of views, 'difficulties in managing open border', 'ambiguous customs policy' and 'poor infrastructure and inconvenient location' are the major issues for customs duty evasion among seven issues.

Table 7

Rank of Various Issues on Customs Duty Evasion in the Views of Government Officials

\begin{tabular}{|c|c|c|c|c|}
\hline Issues of Customs Duty Evasion & & Mean Score & $\%$ & Rank \\
\hline Poor technology adoption & & 2.92 & 12.49 & 7 \\
\hline Political disturbance & & 3.33 & 14.23 & 5 \\
\hline Difficulties in Managing open border & & 3.64 & 15.54 & 1 \\
\hline Poor human resource base & & 3.37 & 14.37 & 4 \\
\hline Ambiguous customs policy & & 3.44 & 14.69 & 2 \\
\hline Poor infrastructure and inconvenient location & & 3.42 & 14.60 & 3 \\
\hline \multirow[t]{2}{*}{ Lengthy customs clearance procedure } & & 3.30 & 14.08 & 6 \\
\hline & Total & 23.43 & 100 & \\
\hline
\end{tabular}

Source: Author's calculation from Survey 2015

\subsection{Seriousness of Overall Respondents on the Issues of Customs Duty Evasion}

From the point of view of overall respondents on the issues related to customs duty evasion, order of seriousness has been presented in Table 8 by ranking the mean scores of seven different issues. The table shows that the mean score of the 'poor technology adoption' is nearly 3 . According to distribution of scale, response at 3 is 'fairly agree' scale of response. However, each of all other issues related to customs duty evasion is nearly 4 scale of response. The scale of response at 4 indicates 'agree'. However, the average of the total mean score is 3.57 (ie., nearly 4). This result also reports that the perception of total respondents is eyeballed as 'agree' on the issues of customs duty evasion.

\section{Table 8}

Perception of Total Respondents on the issues of Customs Duty Evasion with Scale of Responses

\begin{tabular}{|c|c|c|c|}
\hline Issues on Customs Duty Evasion & Mean Score & $\begin{array}{l}\text { Rounding } \\
\text { Scores }\end{array}$ & $\begin{array}{c}\text { Scale of } \\
\text { Response }\end{array}$ \\
\hline Poor technology adoption & 3.28 & 3 & fairly agree \\
\hline Political disturbance & 3.54 & 4 & Agree \\
\hline Difficulties in Managing open border & 3.71 & 4 & Agree \\
\hline Poor human resource base & 3.58 & 4 & Agree \\
\hline Ambiguous customs policy & 3.67 & 4 & Agree \\
\hline Poor infrastructure and inconvenient location & 3.65 & 4 & Agree \\
\hline Lengthy customs clearance procedure & 3.57 & 4 & Agree \\
\hline Average & 3.57 & 4 & Agree \\
\hline
\end{tabular}

Source: Author's calculation from Survey 2015 
As presented in Table 9, average scores are computed and ranked in order of seriousness. According to seriousness of the total respondents on each of the issues, 'difficulties in managing open border' (14.85\%), 'ambiguous customs policy' (14.66\%) and 'poor infrastructure and inconvenient location' $(14.60 \%)$ have been ranked first, second and third respectively, while 'poor technology adoption' (13.11\%) has been ranked seventh as the least serious issue of the customs duty evasion. So, the average views of total respondents points out that 'difficulties in managing open border', 'ambiguous customs policy' and 'poor infrastructure and inconvenient location' are the more influencing factors for the customs duty evasion.

Table 9

Rank of Various Issues on Customs Duty Evasion in the Views of Total Respondents

\begin{tabular}{lccc}
\hline \multicolumn{1}{c}{ Issues on Customs Duty Evasion } & Mean Score & \% & Rank \\
\hline Poor technology adoption & 3.28 & 13.11 & 7 \\
Political disturbance & 3.54 & 14.16 & 6 \\
Difficulties in Managing open border & 3.71 & 14.85 & 1 \\
Poor human resource base & 3.58 & 14.32 & 4 \\
Ambiguous customs policy & 3.67 & 14.66 & 2 \\
Poor infrastructure and inconvenient location & 3.65 & 14.60 & 3 \\
Lengthy customs clearance procedure & 3.57 & 14.30 & 5 \\
\hline & Total & $\mathbf{2 5 . 0 0}$ & $\mathbf{1 0 0}$ \\
\hline
\end{tabular}

The result shows that "difficulties in managing open border" is the most important issue on customs duty evasion. This result is similar to the outcome derived by Paudel and Devkota (2018). They also showed the open border causes tax-evasion. Similarly, the outcome of the result also revealed that "ambiguous customs policy" is another important factor of customs duty evasion. This result is also similar to that of Mishra, Subramanian and Topalova (2007).

They also found that customs tax policy has had significant impact on customs duty evasion. Poor infrastructure and inconvenient location is also important in this study. The result indicates similarity with the study of Edirisinghe (2013). However, the issue on "poor technology adoption" is less important in this study. Growing use of technology might have affected seriousness in the issue.

\section{Conclusion}

From the compare mean test, it is concluded that the views of both groups (business communities and government officials) on different issues related to customs duty evasion are significantly different. From the average views of total respondents on the issues related to customs duty evasion, the average scores lies in "agree" scale of response whereas average views of business communities lies "agree" and views of government official lies 'fairly agree'. These scale of responses evaluated that most respondents consented with the statements under each issue related to customs duty evasion. It was also observed that issues on 'difficulties in managing open border', 'ambiguous customs policy' and 'poor infrastructure and inconvenient location' are seen to be the major issues in customs duty evasion, but respondents are observed to be less serious in the issue of 'poor technology adoption' among the seven issues related to customs duty evasion. However, above result attempts to prove the seriousness of stakeholders on the 
issues related to customs duty evasion.

From the result, it is observed that the most serious issue is 'difficulties in managing open border'. In order to improve this serious issue, the border management agencies should work together and integrate their respective information seamlessly within the requirements of data protection and privacy legislation. They should develop a common vision and an inter-agency approach for implementation of the service delivery. However, the concerned department of government sector, policy maker and planner should pay attention to these major issues to make a good decision for the control in customs duty evasion.

In case of tax administration, if it is efficient and honest, its dealing with taxpayer would be fair. Instead, if it is inefficient and corrupt, it will create unnecessary complexity to taxpayer and affects tax reporting and tax collection as well.

The study also recommends for the valuation systems, legal provision, infrastructure, coordination between government agencies, coordination between Nepalese and Indian customs officials, and unanimous use of an 8-digit HS code between government revenue agencies for controlling customs duty evasion.

\section{References}

Abodher, F. M., Ariffin, Z. Z., \& Saad, N. (2018). Effect of political factors on tax Noncompliance behavior among Libyan Self-employed taxpayers. Academy of Accounting and Financial Studies Journal, 22(4), 1-9.

Adu1, K., Poku, K., \& Anarfi, B. O. (2014). Transit and warehousing activities: A silent wrecker of tax revenue in Ghana. International Journal of Business and Social Research (IJBSR), 4(6), 71-84.

Aisen, A., \& Francisco Jose Veiga, F. J. (2011). How does political instability affect economic growth? (IMF Working Paper 11/12). International Monetary Fund.

Akindele, R. I. (2011). Fraud as a negative catalyst in the Nigerian banking industry. Journal of Emerging Trends in Economics and Management Sciences (JETEMS) 2(5), 357-363.

Amin, A., Nadeem, A. M., Parveen, S., Kamran, M. A., \& Anwar, S. (2014). Factors affecting tax collection in Pakistan: An empirical investigation. Journal of Finance and Economics, 2(5), 149-155.

Awan, A. G. (2014). The determinants of tax evasion in Pakistan: A case study of southern Punjab. International Journal of Development and Economic Sustainability, 2(4), 50-69.

Bhagwati, J. (1964). On the underinvoicing of imports. Bulletin of the Oxford University Institute of Economics and Statistics, 26, 389-397.

Bridi, A. (2010). Corruption in tax administration. U4 Helpdesk Answer, Retrieved from http://www.u4.no /publications /corruption n-in-tax administration. 
Customs Duty Evasion Issues in Nepal

Department of Customs (DoC). (2007). Customs Act 2007 (2064 BS). Kathmandu: Government of Nepal (GoN).

Edirisinghe, L. (2013). Cross-border logistics performance in Sri Lanka: The way forward. International Research Conference on Business \& Information.

Finger, M., \& Schuler, P. (2000). Implementation of uruguay round commitments: the development challenge (Policy Research Working Papers 2215). Retrived from http:// papers.ssrn.com/sol3/papers.cfm?abstract_id=6239721 dated 2009, June 5.

Ghimire, D. (2005). The legislative review study on customs policies of HMG Nepal. Kathmandu: Centre for Public Policy Dialogue.

Ghimire, B. (2006). Study for the Measures of Tax Compliance Habit and Leakage Control (Policy Paper 32). Kathmandu: Economic Policy Network, Ministry of Finanace, GoN and Asian Development Bank, Nepal.

Karimi, H., Kimani, E. M., \& Kinyua, J. M. (2017). Effect of technology and information systems on revenue collection by the county government of Embu, Kenya. International Academic. Journal of Information Systems and Technology, 2(1), 19-35.

Khattry, B., \& Rao, M. (2002). Fiscal Faux Pas? An Analysis of the Revenue Implications of Trade Liberalization. World Development, 30, 1431-1444.

King, J. (2003). Next steps in tax reform-preliminary report Nepal. Washington D.C.: International Monetary Fund.

Mishra, P., Subramanian, A, \& Topalova, P. (2007). Policies, Enforcement, and Customs Evasion: Evidence from India (Working Paper). International Monetary Fund.

MountDigit Technology (2006). An estimated of informal and unauthorised imports from India. Kathmandu: FNCCI Anti-Corruption Project.

MountDigit Technology (2006). An estimated of informal and unauthorised imports from India. Kathmandu: FNCCI Anti-Corruption Project.

OECD. (2014). The role of tax examiners and tax auditors. Retrieved from http://bit. $1 \mathrm{y} / 1$ tor $75 \mathrm{~S}$.

Onogwu, D. J. (2018). Corruption and the efficiency of customs clearance process in selected countries. Review of Public Administration and Management, 6(3), 1-8.

Paudel, D. B. (2010). Do informal economic activities matter for loss of customs revenue in Nepal? In S. P. Dahal, A. P. Shiwakoti, K. R. Jnawali, N. Regmi, \& D. B. Prajapati (Eds.), Customs: $58^{\text {th }}$ International Customs Day Special Issue (pp. 19-24). Kathmandu: Department of Customs, MoF/GoN.

Paudel, U. R., \& Devkota, N. (2018). Socio-economic influences on small business performance in Nepal-India open border: Evidence from crosssectional analysis. Economics and Sociology, 11(4), 11-30. 
Customs Duty Evasion Issues in Nepal

Randrianarisoa, L. M., Bolduc. D., Choo, Y. Y., Oum, T. H., Yan, J. (2015). Effect of corruption on efficiency of the European airports (Working Paper 2015-1). Center for Research on Economics of the Environment, Agri-Food, Transport and Energy (CREATE).

Rege, V. (2002). Custom Valuation and Customs Reform. In B. Hoekman, A. Mattoo, Philip (Eds.), Development, Trade and the WTO: A Handbook (128-138). Washington D.C.: World Bank.

Singh, R. M. (2010). Customs administration: Theory and practice. Kathmandu: Nhooja Guthi.

Singh, R. M. (2010). Customs administration: Theory and practice. Kathmandu: Nhooja Guthi.

Taneja, N., \& Pohit, S. (2004). India's informal trade with Nepal. EGDI and UNU-WIDER Conference, Unlocking Human Potential: Linking the Informal and Formal Sectors, Helsinki, Finland.

Usman, A. (2019). The impact of taxpayer's perception of the integrity and competence of tax officials on companies income tax compliance in Nigeria. Journal of Humanities and Social Sciences, 24(3), 35-45.

Uzzaman, M. A., \& Yusuf, M. A. (2011). The role of customs and other agencies in trade facilitation in Bangladesh: hindrances and ways forward. World Customs Journal, 5(1), $29-42$.

Wei, L. (2013). A perspective on the impact of trade friction on customs performance. World Customs Journal, 7(1), 81-91. 